\title{
THE SEARCH FOR OBJECTIVITY IN CONSTITUTIONAL LAW
}

\author{
GEORGE D. BRADEN†
}

\begin{abstract}
"We may try to see things as objectively as we please. None the lees, we can never see them with any eyes except our own."
\end{abstract}

- Cardozo, The Nolure of the Iuditial Process

THIS is an era of avowed sophistication in the Supreme Court. To talk, as Justice Roberts did, of simply laying a statute alongside an article of the Constitution to see if the former squares with the latter, ${ }^{1}$ now seems almost like dredging up an antiquity. Justices may always have been sufficiently sophisticated to know that the judicial process is not that simple, that in the constitutional field the process is primarily political, not judicial; but it is only recently that they have admitted as much and have begun to discuss publicly their methods of deciding cases. ${ }^{2}$

One can hardly blame the current bench for indulging in this sort of self-analysis, so obviously designed to minimize the significance of "personal predilections." 3 The Court was buffeted enough during the storm over the Constitution ${ }^{4}$ to make the boldest justice keep his neck drawn in. Yet without some external measuring stick of predilection, i.e., a substitute for "personal," no justice has any satisfactory way to avoid either sticking his neck out or being a cipher. If he takes the latter course, he will presumably feel thoroughly frustrated and, if enough colleagues are of like mind, will be effectively helping to destroy the Court's power. Instead, he may acknowledge the political power he possesses and then go on to demonstrate that he has chosen a particular course of action which will narrow the scope of this power. Here the justice seems to be saying: "I admit that Justice Robert's mechanical method of squaring the statute and the Constitution was nonsense. Of course, we wield power. But this is potentially dangerous. Therefore, we must create a rule which is sufficiently objective to circumscribe us and our successors in our exercise of political power."

+ Assistant Professor of Law, Yale Law School.

1. United States v. Butler, 297 U.S. 1, 62 (1936).

2. See, e.g., Adamson v. California, 332 U.S. 46 (1947); Rescue Army v. Municipal Court, 331 U.S. 549 (1947); Louisiana ex rel. Francis v. Resweber, 329 U.S. 459 (1947); West Virginia Bd. of Educ. v. Barnette, 319 U.S. 624 (1943).

3. "It is difficult to imagine any grounds, other than our own personal cconomic predilections, for saying that. . ." Mr. Justice Stone, dissenting in Mforehead $\mathrm{v}$. New York ex rel. Tipaldo, 298 U.S. 587, 633 (1936).

4. See, e.g., Brant, Storar Over the Constitution (1936); Jackso:t, The StaugGLE FOR JUDICIAL SUPREXIACY (1941). 
Thus, the Supreme Court goes galloping off in search of objectivity." This approach is admittedly a far cry from the deceptiveness, selfinduced or not, of the mechanistic approach. But will it produce anything any more satisfactory either to the justices themselves or to the public?

\section{THE ProbleM}

In the broad view of things, the Supreme Court deals on the constitutional level with issues of absolute limitations on governmental power, distribution of power in a federal system, and distribution of power within the elements of the Federal Government. Such issues are of the greatest significance to the people of the country. Into such issues are packed political, economic, and social factors which cannot be anything but decisive, or, if a qualification seems necessary, highly persuasive. Thus the usual constitutional issue acquires non-legal overtones that set it off from most ordinary litigation. ${ }^{6}$ The more insistent the overtones the more difficult it is to confine the issue within legal boundaries, the more necessary it is to rely on extraneous materials to aid in decision. ${ }^{7}$ Furthermore, the nature of the wording of constitutional provisions adds to this difficulty. Provisions run the gamut from definite and precise-". . . each Senator shall have one vote," 8-to semi-definite- "Congress shall make no law . . . abridging the freedom of speech," 9- to hopelessly vague-"The Congress shall have power . . . to regulate commerce with foreign nations, and among the several States. . . " 10 The less definite the provision the more likely it is to be litigated, the more likely are judges to quarrel over meaning

5. By objectivity I mean that quality of a rule of law which enables it to be applied to similar situations with similar results regardless of the identity of the judges who apply it.

6. The analysis of the judging process herein discussed is limited to constitutional issues in the Supreme Court. When it comes to statutory interpretation or common-law adjudication, other factors enter which change the emphasis of factors herein discussed. Likewise, lower federal courts and state court systems differ from the Supreme Court so much that a completely new analysis would be necessary.

7. See generally Hamilton and Braden, The Special Competence of the Supreme Court, 50 YALE L. J. 1319, esp. pp. 1324-34 (1941). It has been said of this article that it is "the source of one of the leading current doctrines of judicial review." Commont, The Image in the Mirror, 56 YALE L. J. 1356, 1357 n.3 (1947). Assuming that this is a compliment, I must hasten to protect myself, and perhaps by inference, Mr. Hamilton, against a charge of inconsistency, for the implication in the quotation above is that we propounded an "objective" theory of judicial review. Hence I point out first, that in large measure the criterion of "competence" is a suggested philosophy for the Court on the level of "procedural values", p. 577 infra; and second, that the concluding two paragraphs of our article carefully noted that even if our criterion were accepted, it still left "wide margins" for individual justices in furthering their "convictions of the "Good Society." See pp. 1374-5.

8. U.S. Const. Art. I, $\$ 3$.

9. U.S. Const. AMENd. I.

10. U.S. Const. Art. I, §8. 
or to stray beyond the four corners of the document, and the more likely that over a period of time different courts will read the provision differently in the light of their own times. The upshot is that where the Court usually acts, its freedom is greatest.

If the Court had to speak on every broad issue that came to it, it might in the short run formulate a comprehensive constitutional philosophy for its day. But it sits as a court of law and it has at hand a wealth of techniques that enables it to broaden or narrow, resolve or avoid, the constitutional issues brought before it. This compounds the confusion. For example, the Court can make something "constitutional" or "unconstitutional" without saying so, ${ }^{11}$ or it can assist or hinder another arm of government without addressing itself to the constitutional issue of distribution of power. ${ }^{12}$

The Supreme Court starts, then, with a fundamental document, the more important provisions of which are hopelessly vague. It is presented with momentous questions, but they come to it via a system that is flexible enough to premit reshaping of the issues. To all this can be added a century and a half of gloss wherein each generation interpreted the document to fit its environment. With the changes in external factors through the history of the country, the stock of interpretations has become large and varied so that today the Court has almost unlimited verbal devices for justifying anything it does. Small wonder then, that individual justices search for ways to control themselves and their brethren.

\section{The Freedoar of a Justice}

Notwithstanding the present welter of confusion which gives the Court such freedom of action, there are limiting factors. Before weighing the worth of the theories of self-limitation propounded by members of the Court it is worthwhile to see what exists apart from any theory. It is also well to examine this freedom against which so many theories of self-limitation are set up. With these two pre-existing opposites set forth, the new theories may be evaluated.

If one assumes for purposes of analysis the extremes of freedom pos-

11. E.g., the Illinois statute governing Congressional districts was "constitutional" because the Court would not pass on the question. Colegrove v. Green, 328 U.S. 549 (1946). The Civil Rights Act was construed narrowly to avoid grave constitutional doubts; hence, the broader meaning is "unconstitutional." Screws v. United States, 325 U.S. 91 (1945).

12. E.g., in Perkins v. Lukens Steel Co., 310 U.S. 113 (1940), the Court prevented an attack on an administrative interpretation of a statutory delegation by the technical finding of lack of standing to sue. In Spector Motor Service v. MrcLaughlin, 323 U.S. 101 (1944), the Court refused to pass on the validity of a state statute because the state courts had not construed the statute. The issue was a tax assessed for the years 1937-40. As of March 1948, the state case was pending before the Connecticut Supreme Court of Errors. Thus the state government continues to be in doubt. 
sessed by any majority of the Supreme Court, there are only four absolute limitations on their power. First, a possible constitutional issue must be brought before them. This is not meant in the sense of the legal lore of "case or controversy" but in the literal sense of finding one person who wishes to raise the issue. To put it absurdly, if no one in the United States except five members of the Court wishes a course of action interdicted on constitutional grounds, there is no way to do it. If the five members simply issue a public statement under these assumed conditions, presumably no one will pay any attention to it. As a corollary to this, there must be an affirmative step threatened by someone which is susceptible to invalidation. Five justices cannot arise one day and announce that it is unconstitutional for Congress not to appropriate a billion dollars for psychical research. They may arise and speak, but they will go unheeded. ${ }^{13}$ A second absolute limitation is the probability of obedience. A majority of the Court will not follow a course of action which they believe will openly and literally be flouted, for by doing so they will be consciously destroying their effectiveness. Thirdly, they will not follow a course of action which they believe will lead to a successful court-packing or similar plan aimed at them. Finally, they will not follow a course of action which they believe will lead to their impeachment. ${ }^{14}$

These are rather absurd limitations, but they are the only absolutes. Any others are subject to intellectual, verbal, call it what you will, manipulation in such a way as to provide some loophole for escape if necessary. For example, there must by tradition be a "case or controversy." If the Court feels strongly enough about a matter which some one attempts to bring, it is possible either to squeeze the subject matter into the concept of a "case or controversy," or, if necessary, to avoid the concept by some such red herring as "It is not for this Court to deny redress of this grievous wrong solely because the wrong cannot be set forth in orthodox terms. The great protection of the Constitution will not be vitiated by such stultifying legalisms." 15 Similarly, the Court can literally manipulate "standing to sue," stare decisis, "political" questions, and all other procedural aspects of constitutional law.

13. In either case, the grounds for ignoring the Court would involve talk about "case or controversy." Where a person seeks to get an isstue litigated the Court can, as I argue in the next paragraph, manipulate the concept of "case or controversy." But where the Court speaks ex mero motil, I see no way for it to avoid the restrictive concept.

14. The third and fourth limitations are perhaps spurious. The Court could denounce a court-packing plan or an impeachment as unconstitutional. Thus the "absolutely absolute" limitation becomes the second. Even here there is a qualification to be made. The court might follow a course which they knew would be flouted by another arm of the government because they wanted to create a dramatic situation for immediate political use or for future judicial use. Cf. Ex parte Merryman, 17 Fed. Cas. 144, No. 9,487 (C.C.D. Md. 1861).

15. Cf. Stark v. Wickard, 321 U.S. 288, 309-10 (1944). 
Obviously, the Court does not lightly manipulate these traditional devices. There are other limitations on its freedom. These are of two kinds: those which are self-imposed (except to the extent that they are conditioned by the last three of the absolute limitations noted above); and those which are aspects of the individual justice's personality.

Of this latter group there is first the individual's intellectual capacity. Freedom, as discussed here, rests upon an assumption of infinite intellectual ability to spin out words to justify what is done, to present action in a non-startling fashion, to forestall excessive criticism-in short, to prevent the uninitiated from losing faith. Each individual justice has capacity short of the infinite. The less the capacity, the less the ability either to perceive the rhetorical techniques for doing what is wanted or to use them confidently enough to succeed.

More important than intellectual capacity is the individual's intellectual fortitude. Justices may be able to exercise considerable freedom but they may lack the courage to do so. This lack of courage is, of course, conditioned by other factors already discussed. Action may not be taken because of a fear that it will lead to a destruction of the Court -in other words, an anticipation of an absolute limitation. Or action may not be taken because of lack of confidence in intellectual capacity. It is enough to describe such courage or the lack of it as a shorthand expression of an individual justice's appraisal of the chances of exercising power and yet preserving that power for the future. ${ }^{10}$ To the extent that his appraisal is erroneous, he is unnecessarily limiting his own freedom.

Closely related to capacity and fortitude are other aspects of the justice's personality which affect his freedom. For example, justices " may be sensitive to criticism which is far short of a threat to their power. Another example is capacity for work. In some cases a great deal of agility may be required to present a point of view, and the labor may not be worth the candle or the time required may not be available. Or there is inertia. If a justice does not feel strongly on a subject he may follow the line of least resistance and uncritically rely on what has gone before. ${ }^{17}$

In considering these personality factors circumscribing a judge, it must be noted that they operate in two ways. First, they are to some extent absolute in that they control the judge regardless of his personal

16. In many instances, what appears to be lack of courage may in reality be an unusually strong acceptance of one of the self-imposed limitations diseussed pp. $576-7$ infro. Cf. Hand, Thomas Walter Sivan, 57 Y ALE L.J. 167 (1947).

17. A law clerk in a circuit court of appeals once told me that his judge asked him to look up the "law" on a case under consideration. Upon learning that the precise issue had been decided by another circuit, the judge said that he would simply follow the other circuit and forget about the problem. 
inclination. An extremely stupid man may not, for example, be able to see his way around a precedent. Or an extremely busy man may not have the time to work out a method of avoiding the obvious. Second, and more to the point, these factors are relative in that their restrictive effect is a measure of the importance of the issue involved. The more important the issue to the judge, the less he will be restricted. Conversely, the more trivial the issue, the more likely he will lack "courage," or be too "busy," or fear "criticism."

The final class of limitations consists of those which are self-imposed. One of these is the urge for "consistency": presumably, the Supreme Court wishes to be consistent both because consistency is intellectually satisfying and because it is an important tenet of Anglo-American jurisprudence. Though this be true, the fact remains that the Supreme Court does not have to be consistent except to the extent that it believes the absolute limitations on its power will be called forth if it is inconsistent, Furthermore, "consistency" is a slippery business. Two given decisions are consistent or inconsistent only in terms of the larger frame into which they are put. For example, two interstate commerce tax cases may be consistent on a theory that a direct tax on an interstate "sale" is invalid; but they may be inconsistent on a theory that interstate sales taxes are invalid only if there is a likelihood of multiple taxation. ${ }^{18}$ The degree of consistency may be principally a matter of articulateness in explaining the theory of decision. Beyond this, it must be conceded that American judges seek to be consistent on some level. And where the course of decision has been consistent over a long period of time, the urge for consistency may outweigh the dislike for the course of decision. ${ }^{19}$

Another self-imposed limitation may be denominated "avoidance of confusion." If the assumptions which have just been set out are correct, the Supreme Court possesses a broad freedom to do as it wishes in constitutional cases. But in exercising that freedom it must not create too much immediate confusion. It is the ultimate spokesman in the judicial hierarchy and the lesser spokesmen must pay heed. If the Supreme Court pursues policies which lesser spokesmen, using the same techniques which the Supreme Court uses, can twist into opposites, the Supreme Court vitiates its own influence. This may very well be the most effective limitation on the Supreme Court's power. If the opinion of the Court were significant only as a justification of the action taken in the case before it, the entire range of verbal legerdemain might be safely employed. Unfortunately, the Court's every word must be set

18. See the various opinions in Freeman v. Hewit, 329 U.S. 249 (1946), 56 Y AlE L. J. 898 (1947), as to whether the "Court was there consistent with a line of cases ending with McGoldrick v. Berwind-White Coal Co., 309 U.S. 33 (1940). See Dunham, Gross Receipts Tazes on Interstate Transactions, 47 Coz. L. Rev. 211 (1947).

19. See generally Radin, The Trail of the Calf, 32 Cons. L. Q. 137 (1946). 
down with an eye to its meaning in the future in similar situations, in analogous situations, even in irrelevant situations. The Supreme Court knows how far it has gone and can safely decide whether to stay there. It cannot be sure where it will be taken by others before it can call a halt. Put another way, just as the Supreme Court can manipulate the words of the Constitution, so lower courts, administrators, lawyers, and others can manipulate the words of the Supreme Court. ${ }^{3-0}$ It might almost be asserted that what makes the law tolerably consistent is not adherence to the past but fear of over-committing the future.

The final limitation on the individual justice's freedom to be suggested here as "self-imposed" is a hybrid in that it may be a limiting factor or it may not. This is what may be called the "concept of the judicial function." If a justice believes he should have no power it is conceivable that he may put his belief into practice. On the other hand if he believes that he should have great power, his freedom may be enhanced by a sort of auto-intoxication. But several careats must be entered. First, the word "believes" is stressed because it is important to distinguish between belief and profession of belief. Nothing is easier for a justice than to profess not to do that which he does. Second, a justice's concept of the judicial function may simply be an expression of his scheme of values-e.g., this is important, I must pass on it; that is not important, ergo I have no power to pass on it. Third, it is a limitation which is profoundly affected by all the limitations outlined above. Any concept of the judicial function must include an appraisal of the power one possesses and one's competence to exercise that power. Finally, in so far as the concept of the judicial function is a limitation over and above an appraisal of power possessed, it is easily changed. It is of the essence of "self-imposedness."

These are all factors limiting the freedom which a justice in theory enjoys, a freedom to reshape contemporary American society according to his own scheme of values. In venerable legal tradition these values may be divided into substantive and procedural. Substantive values will probably consist of beliefs concerning strong unionism, abolition of racial discrimination, curtailment of business monopolies, public ownership of public utilities, socialized medicine, religious freedom, and so forth. Procedural values will probably consist of beliefs concerning democracy, republicanism, federalism, states' rights, centralization of

20. It has seemed to me that Judge Iearned Hand has on occasion said to himself that the Supreme Court was going too far along some line and undertaken to prove it by an almost absurd extrapolation which the Court has had to reverse, thereby proving his point. See United States exr rcl. MIcCann v. Adams, 126 F.2d 774 (C.C.A. 2d 1942), rev'd, 317 U.S. 269 (1942), and United States c.r rel. Kulick v. Kennedy, 157 F.2d 811 - (C.C.A. 2d 1946) rev'd sub nom. Sunal v. Large, 332 U.S. 174 (1947). See also his comments about the Dobson rule in Brooklyn Nat. Corp. v. Commissioner, 157 F.2d 450 (C.C.A. 2d 1946) and in Kirschenbaum v. Commissioner 155 F.2d 23 (C.C.A. 2d 1946). 
power, rule by executive power, preservation of checks and balances, and so forth. In addition, there may be more abstract and vague values such as fair play, dignity of the individual, and even justice.

Once those values are set forth, their interaction must be considered. A justice may favor private control of public utilities but he may believe in democracy so strongly that he will not attempt to protect utilities from legislative control. Or a justice may wish to support religious freedom but may believe in state's rights so strongly that he will let individual states tamper with it. These relationships will, to some extent, be altered by the degree of intensity with which each belief is held, so that interaction may produce different results in different instances. For example, religious freedom may be important enough to outweigh legislative support of patriotism by flag salutes but not to outweigh legislative protection from excessive ringing of doorbells. Moreover, an individual may abstractly favor one course of action except when he sees that furthering it affords protection to a disfavored course of action. For example, a justice may deplore certain searches and seizures, but he will not fight them too hard for fear that business will seek shelter behind such a shield and effectively forestall certain types of governmental economic regulation.

What is the situation facing the individual justice if his scheme of values and the limitations on his freedom are brought together in the context of a constitutional issue? Clearly there is an interaction of three variables. First, the constitutional provision involved may be definite or vague, the posture of the case clear-cut or fuzzy. For example, Congress said in 1940 that for purposes of diversity of citizenship jurisdiction, citizens of the District of Columbia should be eligible to sue or to be sued in Federal courts. ${ }^{21}$ But the Constitution says in this context that jurisdiction shall extend only to controversies between "citizens of different States." ${ }^{22}$ It is simple to decide that the jurisdictional grant is unconstitutional. ${ }^{23}$ To decide otherwise requires considerable spinning out of sophisticated argument. Second, the justice has a scheme of values. He may feel that in this case Congress ought to be allowed free rein in setting the rules for jurisdiction, or he may dislike diversity jurisdiction. He may feel strongly about the general "orphan" status of Washingtonians, or he may feel that corporations "unfairly" benefit from diversity jurisdiction and may believe that

21. 54 Stat. 143, 28 U.S.C. $\$ 41$ (1) (1940).

22. U.S. Const., Art. III, $\$ 2$.

23. The provision was held unconstitutional in Feely v. Schupper Interstate Hauling System, 72 F. Supp. 663 (D. Md. 1947) ; Ostrow v. Samuel Brilliant Co., 66 F. Supp. 593 (D. Mass. 1946) ; Behlert v. James Foundation, 60 F. Supp. 706 (S.D.N.Y. 1945); and McGarry v. City of Bethlehem, 45 F. Supp. 385 (E.D. Pa. 1942). Contra: Glaeser v. Acacia Mut. Life Ins. Co., 55 F. Supp. 925 (N.D. Cal. 1944); Winkler v. Daniels, 43 F. Supp. 265 (E.D. Va. 1942). 
the Congressional grant would increase these "unfair" corporate benefits. ${ }^{24}$ Third, various limiting factors affect him. He will be aware that this is not a political hot potato, that it is peculiarly a "judicial" question, and that whatever is decided will probably be free from confusion, at least in the sense that lower courts will not be able to twist things around. But he will be aware also that there is considerable judicial lore about "constitutional" courts and "legislative" courts in the District which might require extensive juggling if consistency is to be preserved. ${ }^{25}$ Putting all this together, if the justice wants to uphold the Congressional grant he can do so without fear but not without considerable work. In this instance, then, the work involved can be set against the importance of upholding the grant of jurisdiction. Other examples will produce different key factors, but no matter how the factors are set up and evaluated, the justice must end by deciding how important the issue is within his total scheme of values. And if the issue is important enough nothing will stop him except the absolute limitations on his power.

A justice may therefore do one of two things. He may admit to himself that he decides constitutional questions in the light of his own scheme of values and then expound these values for all to see. Or the justice may deny this concept of freedom and personal values and assert that his decisions are based entirely and objectively on external factors. Whichever course is followed, the question is: how impregnable can the justice make his position? If his is a philosophy of personal freedom, can it be set up so that in the future it is self-executing? If on the other hand his philosophy is one of external considerations, can a third person look at his external scheme and find the same answer?

\section{EFForTs AT SelF-Lmitation}

One of the first of recent efforts by justices to make explicit a philosophy of self-limitation appeared in Chief Justice Stone's now famous footnote in the otherwise little noticed Carolene Producls case. ${ }^{n}$ He was there addressing himself to a problem arising out of the use of the presumption of constitutionality as a means of forestalling Due Process Clause attacks on economic legislation. His problem was to make the

24. See generally McGovney, A Sutreme Court Fiction, 56 Hanv. L. Rev. 853, 1090,1225 (1943).

25. The Court, having differentiated the District of Columbia from the rest of the country and thus created a concept of "legislative" courts differing from "constitutional" courts under Article III, could be plagued with such a differentiation if it sought to assert that the District was no different from a "state" as used in Article III. The principal cases are Federal Radio Comm. v. General Elec. Co., 281 U.S. 464 (1930); Keller v. Potomac Elec. Power Co., 261 U.S. 428 (1923); cf. O'Donoghue v. United States, 289 U.S. 516 (1933).

26. United States v. Carolene Products Co., 304 U.S. 144 (1938). 
presumption stick in economic cases without being plagued by it in civil liberties and similar cases. Accordingly, he suggested by typical judicial indirection that legislation restricting political processes and legislation directed at "discrete and insular" minorities should not have a favorable presumption of constitutionality to protect the legislation against attack. ${ }^{27}$ His expressed reason for the latter half of this was that political processes "can ordinarily be expected to bring about repeal of undesirable legislation," but that minorities such as racial and religious groups are subject to prejudice "which tends seriously to curtail the operation of those political processes ordinarily to be relied upon to protect minorities. . . ."28

Chief Justice Stone's thesis appears to be something like this: "I am first of all a man of reason. I believe in reason and its power in the market place of discourse. I am also a democrat. I believe that our govern-

27. Id. at $152-3$, n.4.

28. Ibid. This now famous footnote is not without its ambiguity. There are three paragraphs to it. The second deals with restrictions on political process and the third deals with minorities. The first paragraph appears to be unnecessary, if not actually inconsistent with the remainder of the footnote. This paragraph argues that "there may be narrower scope for operation of the presumption of constitutionality when legislation appears on its face to be within a specific prohibition of the Constitution, such as those of the first ten amendments. ..." Such an argument either obviates the necessity for speaking, as the second paragraph does, of restrictions on political processes if the First and Fifteenth Amendments cover political processes, or is not exhaustive if non-specific prohibitions must be relied on to protect political processes. Likewise, the third paragraph on minorities is potentially more extensive than any specific prohibitions contained in the Constitution. (Cf. p. 591 infra, as to "equal protection.")

I am forced to conclude either that Mr. Justice Stone was setting forth confusing arguments or that he did not write the first paragraph. I incline to the second alternative partly because the paragraph does not fit in with what appears to be his philosophy and partly because two dicta are referred to to support the first paragraph, Stromberg v. California, 283 U.S. 359, 369-70 (1931) and Lovell v. Griffin, 303 U.S. 444, 452 (1938), both opinions of Chief Justice Hughes, which references seem only vaguely relevant. Both references say that the legislation there under review is invalid on its face. There is no hint that any fundamental constitutional theory is set forth. Furthermore, I should think that legislation not within a "specific" prohibition of the Constitution could still "appear on its face" to be invalid and would be so declared, as for example, an act of Congress purporting to regulate "commerce not interstate or affecting such," or a state statute which purported to take property from $A$ and give it to $B$ simply because the legislators disliked $A$. (Cf. Davidson v. New Orleans, 96 U.S. 97, 102 (1878)). My gucss is that Chief Justice Hughes added the paragraph to protect some theory he had which he thought the citations to his opinions demonstrated.

If $\mathrm{I}$ am right, it is unfortunate that the first paragraph got carried along as part of Chief Justice Stone's philosophy. See Konefsky, Chief Justice Stone and the SuPREME COURT, 195 (1945); Wechsler, Stone and the Constitution, 46 Col. L. Rev. 764, 795-6 (1946) ; cf. Frankfurter, J., dissenting in West Virginia Bd. of Educ. v. Barnette, 319 U.S. 624, 648 (1943), wherein he cites the footnote to support the Court's recognition that the prohibitions of the Bill of Rights are specific. But see Lusky, Mintority Rights and the Public Interest, 52 YaLE L. J. 1, 20 (1942), where the footnote is quoted in full except that the first paragraph is omitted. 
ments are to be run by the governed. Therefore I shall use my great power as a Supreme Court justice sparingly, but I shall use it when it is necessary to preserve the democratic process or to protect those injured by unreason under circumstances where political processes cannot be relied on to protect them."

Shortly before the Carolene Products case he expressed much this same notion as a guide in umpiring the Commerce Clause. $\cong$ He first noted that the Court had frequently struck down state legislation affecting interstate commerce where the purpose was to benefit the local citizens at the expense of the outlander. Then he expressed the thought "that when the regulation is of such a character that its burden falls principally upon those without the state, legislative action is not likely to be subjected to those political restraints which are normally exerted on legislation where it affects adversely some interest within the state."

Here then is a statement of a basic formula for constitutional decisions in certain areas. It is not a statement which can be found in the Constitution or in the Court's gloss on the Constitution. It is rather one man's explanation of why he finds the Due Process and Commerce Clauses to be limitations on government in some instances and not in others. Put another way, it is simply a part of one man's set of values for his society which he holds strongly enough to be willing to enforce when the opportunity arises.

An analysis of this philosophy reveals some shortcomings. In the first place, it is open-ended. What are "discrete and insular minorities"? Racial and religious groups, yes. Public utilities? Had Chief Justice Stone sat on the Court in the days of Granger legislation against the railroads, would he have held the railroads to be such a minority? ${ }^{31}$ In the second place, such a philosophy based on reason may work in reverse in that a justice unable to see any validity in any argument advanced in support of a legislative act may conclude that it is irrational legislation and hence aimed at a "minority." Third, it is not a complete blueprint. It says that delicate weighing is required when the legislative assertion of necessity is attacked in the name of protection of political processes or of minorities, but it does not give the balance point on the scales. True, no man can anticipate the minor premises that will be brought to him. A working philosophy can not be completely blueprinted; it must grow by experience. But Chief Justice Stone's philosophy is so abstract that it contains virtually nothing to show how it works in individual cases. Would he have dissented in

29. South Carolina Hwy. Dept. v. Barnwell Bros., 303 U.S. 177, 184-5, n.2 (1938).

30. Ibid. Cf. Southern Pacific Co. v. Arizona, 325 U.S. 761 (1945), where he appears to have modified, if not abandoned, this view.

31. See 2 Warren, The Supreare Court in Usited States History, 574-95 (2d ed. 1928). 
Colegrove ข. Green, ${ }^{32}$ where the Court refused to remedy unbalanced representation in Congress? With regard to minorities, did he scrutinize severely "legislation directed at" or "legislation affecting" minorities? Did he require some objective mark of minority status, such as color, to bring his philosophy into effective operations? ${ }^{33}$

This is not an objective theory of judicial review. The Chief Justice never claimed that it was. A man who said "the only check upon our own exercise of power is our own sense of self-restraint" " 34 could hardly believe in any self-executing objective standard of constitutionality. It is perhaps unfair to set forth his thesis as an example of the effort to catch the will-o'-the-wisp of objectivity, but it does seem appropriate to present it as an early attempt to do the next best thing-i.e., to make an open declaration of personal beliefs. Chief Justice Stone may not have stricken out the "personal" in "personal predilection"; he did evolve a well-considered personal philosophy of self-limitation and present it for public criticism as such.

Mr. Justice Frankfurter has likewise come forth with a well-considered philosophy of judicial restraint in areas of limitations on government, but he departs from Chief Justice Stone in presenting his as objective and impersonal. His starting point is the necessity for judicial self-restraint, especially when deciding constitutional questions of limitations on government as in the case of the Fourteenth Amendment. ${ }^{35} \mathrm{He}$ is apparently prepared to accept as a minimum of power the protection of political processes, the first half of Chief Justice Stone's thesis. In his exhaustive statement of his creed in the second flag salute case, he notes that the "channels of affirmative free expression" were open to the Jehovah's Witnesses, the opponents of compulsory flag saluting. ${ }^{36}$ "Had we before us any act of the state putting the slightest curbs upon such free expression, I should not lag behind any member of this Court in striking down such an invasion of the right to freedom of thought and freedom of speech protected by the Constitution." ${ }^{37}$ Inasmuch as the Fourteenth Amendment, under which the flag salute case was brought, says nothing about freedom of thought

32. 328 U.S. 549 (1946).

33. See Lusky, supra note 28 , at $28-30$, where it is suggested that Betts v. Brady, 316 U.S. 455 (1942), might be distinguished from Powell v. Alabama, 287 U.S. 45 (1932), because the latter involved Negroes, the former, a white man. The analysis may be accurate as to Chief Justice Stone's vote. The subsequent confusion in the denial of counsel cases indicates that color is not decisive. Compare, e.g., the successful attack in $\mathrm{De}$ Meerleer v. Michigan, 329 U.S. 663 (1947) (white man semble), with the unsuccessful attack in Carter v. Illinois, 329 U.S. 173 (1946) (Negro).

34. Dissenting in United States v. Butler, 297 U.S. 1, 79 (1936).

35. West Virginia Bd. of Educ. v. Barnette, 319 U.S. 624, 647-8 (1943).

36. Id. at 664 .

37. Ibid. 
or speech, Mr. Justice Frankfurter must have some reason for reading such freedom into the Due Process Clause. That his reason apparently is much the same as the Chief Justice's is fairly inferred from these quoted statements and from his concluding words in his opinion for the Court in the first flag salute case. ${ }^{35}$ There he exalts the role of the legislature, provided that "all the effective means of inducing political changes are left free from interference." 39

It is equally apparent that Mr. Justice Frankfurter does not accept Chief Justice Stone's protection of minorities. The fact that the two men opposed each other in both flag salute cases is enough in itself to establish this. If Mr. Justice Frankfurter stopped with his thesis in those two cases it might be possible to state that he has a personal philosophy even narrower than that of Chief Justice Stone, possessing the best qualities of the latter's without some of the shortcomings noted above. ${ }^{40}$ But he does not stop there. He casts his theory in such a way as to make it objective. First, he makes reference to "specific" prohibitions in the Constitution, using as an example the Bill of Rights, adding that each is as important as the next one. 41 Inasmuch as the First Amendment protects political processes, ${ }^{\text {s2 }}$ he could rely on this "specific" provision were it not for the problem of getting the First Amendment into the Fourteenth. He is not willing to import all the Bill of Rights into the Fourteenth, ${ }^{43}$ and must therefore provide a basis for discriminating between parts of the Bill of Rights, rejecting some and accepting others for purposes of enforcing the Due Process Clause of the Fourteenth Amendment. It is in setting forth the criterion for discrimination that his objective theory takes shape.

This objective criterion is most frequently expressed in words of MIr. Justice Cardozo. For example, on one occasion MIr. Justice Frankfurter relies on his predecessor's words when he says, "Tre are dealing with principles of liberty and justice 'so rooted in the traditions and conscience of our people as to be ranked as fundamental'-something without which 'a fair and enlightened system of justice would be impossible." "44 Again he says, "insofar as due process under the Fourteenth Amendment requires the States to observe any of the immunities 'that

38. Minersville School Dist. v. Gobitis, 310 U.S. 586,600 (1940).

39. Ibid.

40. See p. 581 supra.

41. West Virginia Bd. of Educ. v. Barnette, 319 U.S. 624, 648 (1943).

42. In part, that is. The Fifteenth Amendment is also relevant.

43. See Adamson v. California, 332 U.S. 46, 59-6S (1947), for his latest statement. I do not mean to imply that were he to take the Bill of Rights into the Fourteenth Amendment he would have an objective theory. See pp. 589-93 infra, for the discussion of Mr. Justice Black's attempt to solve the problem in such a manner.

44. West Virginia Bd. of Educ. v. Barnette, 319 U.S. 624, 652 (1943), quoting from Snyder v. Miassachusetts, 291 U.S. 97, 105 (1934), and Palloo v. Conneeticut, 302 U.S. 319, 325 (1937). Mr. Justice Frankfurter credits only the Pallo case but an examinz- 
are valid as against the federal government by force of the specific pledges of particular amendments' it does so because they 'have been found to be implicit in the concept of ordered liberty, and thus, through the Fourteenth Amendment, become valid as against the States. " "45 On occasion he quotes from others, ${ }^{46}$ and sometimes phrases the criterion in his own words. ${ }^{47}$ It all adds up to fundamental notions of justice and liberty.

The important point, of course, is Mr. Justice Frankfurter's assertion that these are not his fundamental notions. In the Willie Francis case, he says, in a concurring opinion, "We cannot escape acknowledging that [the problem before us] involves the application of standards of fairness and justice very broadly conceived. They are not the application of merely personal standards but the impersonal standards of society which alone judges, as the organs of Law, are empowered to enforce." 48 And again in the same opinion he says, "I cannot rid myself of the conviction that were I to hold that Louisiana would transgress the Due Process Clause if the State were allowed in the precise circumstances before us, to carry out the death sentence, I would be enforcing my private view rather than that consensus of society's opinion which, for purposes of due process, is the standard enjoined by the Constitution." 49

Mr. Justice Frankfurter's thesis would thus appear to be somewhat as follows: "I do not let any personal views of my own govern my decisions. I decide cases only on the basis of the consensus of society's opinion of what are fundamental standards of fair play and justice. Naturally, I must have a constitutional provision through which this consensus of opinion can express itself."

Many questions come to mind at once. What is this consensus? Is it qualitative or quantitative? Is it nationwide or broken into statewide

tion of the opinion discloses that Mr. Justice Cardozo was in part quoting from his own opinion in the Sinyder case.

45. Louisiana ex rel. Francis v. Resweber, 329 U.S. 459, 468-9 (1947), quoting from Palko v. Connecticut, 302 U.S. 319, 324-5 (1937).

46. In his concurring opinion in Louisiana ex rel. Francis v. Resweber, 329 U.S. 459, 470 (1947), he says: "When the standards for judicial judgment are not narrower than 'immutable principles of justice which inhere in the very idea of frec government,' Holden v. Hardy, 169 U.S. 366, 389 [(1898)], 'fundamental principles of liberty and justice which lie at the base of all our civil and political institutions,' Hebert v. Lotisiana, 272 U.S. 312, 316 [(1926)], . . . great tolerance toward a State's conduct is demanded of this Court." Mr. Justice Brown was the spokesman in the Holden case, Mr. Justice VanDevanter, in the Hebert case.

47. See text quotations accompanying notes 48 and 49 infra. Sce also Haley v. State, 68 Sup. Ct. 302 (1948) where he concurs specially, reiterating his thesis and adding to it by noting that he personally does not believe in capital punishment or in the use of conventional criminal process where fifteen-year-old offenders are involved, but would not in the name of due process of law impose such personal beliefs on the states. Id. at 305.

48. Louisiana ex rel. Francis v. Resweber, 329 U.S. 459, 470 (1947).

49. Id. at 471 . 
segments? If nationwide, is it determined by a majority of states or a majority of people? What is it a consensus of? Abstract notions of fair play and justice? Or an opinion on the third degree, or flag-saluting, or racial segregation? Or an opinion on the given case before the Court? And how does a justice, who knows what he is looking for, find it? By a Gallup Poll? By editorials in leading papers? By the number of committees of substantial citizens who support the notion? By the number of briefs amici curiae filed? By the number of states which follow a given course? Mr. Justice Frankfurter has given little indication of his answers to these questions.

It is, of course, obvious that he must start with constitutional provisions. The Fourteenth Amendment says that "No state shall. . . ." "ז One would think that this implied a national prohibition against something and thus that the consensus of opinion on fundamental justice would be nationwide. But Mr. Justice Frankfurter appears not to accept this initial determination of the nature of his consensus. In trying to explain that disagreement among his brethren "is not disproof that general rather than idiosyncratic standards are applied," he says: "An important safeguard against such merely individual judgment is an alert deference to the judgment of the State Court under review."'1 This may mean that he thinks that state judges are peculiarly well equipped to ascertain the consensus of society's opinion. Such an interpretation of his words would imply that provincial judges are more discerning in their scrutiny of the national scene than are national judges. If this were his belief, he would effectively destroy his own job. Another possible interpretation of his words is that he believes that the consensus of society's opinion is found by ascertaining the consensus of judges' opinions of what they think is the consensus of society's opinion. But this presupposes that any other judge who has thought about the matter under review used the same formula of objectivity that Mr. Justice Frankfurter uses. It hardly seems likely that he would vitiate his search for fundamental justice by accepting a consensus of the opinions of judges of whom some may have had "idiosyncratic" notions of justice.

The most obvious interpretation of his words is that he thinks fundamental notions of justice are compartmentalized within state boundaries. Other statements of his might lend support to this. For example, in a context of contrast between federal criminal justice and state criminal justice he once said, "Review by this Court of state action expressing its notion of what will best further its own security in the administration of criminal justice demands appropriate respect for the

50. U.S. Const. AMrend. XIV, $\$ 1$.

51. Adamson v. California, 332 U.S. 46, 68 (1947) (concurring opinion); the same language appears in his concurring opinion in Mfalinski v. New York, 324 U.S. 401, 417 (1945). 
deliberative judgment of a state in so basic an exercise of its jurisdiction." ${ }_{22}$ Unfortunately, this interpretation falls to pieces because he sometimes votes against state judges. ${ }^{53}$ In one such case, he made the same remark about "deference" quoted above ${ }^{54}$ and then immediately added, "but there cannot be blind acceptance even of such weighty judgment without disregarding the historic function of civilized procedure in the progress of liberty." 55

Thus the consensus cannot be national, else there is little reason for deferring to a state court, but by the same token it is not state-enclosed, else blind acceptance must be given. What is it? Perhaps one counts individual state judgments. This theory might be substantiated by $\mathrm{Mr}$. Justice Frankfurter's use in a federal searches and seizures case of the significance of a similar provision in the constitutions of all 48 states."0 On the other hand there were apparently only 18 states that required a compulsory flag salute when he first wrote on that issue. ${ }^{67}$ But then perhaps negative votes cannot be counted, for if they can be he should have voted against the legislation. In any event, he has no more clearly indicated that he uses this as a counting device than he has indicated whether a national or state consensus is involved.

This discussion of national or statewide consensus of society's opinion as to fundamental justice is pertinent in relation to the Fourteenth Amendment and state governmental activity. With reference to the Bill of Rights and national governmental activity the situation is changed. Here Mr. Justice Frankfurter does not appear to rely on the consensus of society's opinion. This may be either because he believes the very existence of the Bill of Rights is per se an objective manifestation of the consensus or because he believes that he must enforce the Bill of Rights regardless of society's opinion. If the first reason is correct, he has accepted a national consensus as to the Federal Government which is not the same as the consensus as to states..

If the second reason is correct, his objective standard becomes confused indeed. He seems to be saying that he will use the consensus of society's opinion only when he has a vague constitutional provision, such as the Due Process Clause, before him. But if, as he says, the justices are "set apart" in order "to take a view of longer range" than

52. McNabb v. United States, 318 U.S. 332, 340 (1943).

53. E.g., in Everson v. Board of Education, 330 U.S. 1 (1947) (dissenting); DeMeerleer v. Michigan, 329 U.S. 663, (1947) ; Pennekamp v. Florida, 328 U.S. 331 (1946); Malinski v. New York, 324 U.S. 401 (1945).

54. See text quotation accompanying note 51 supra.

55. Malinski v. New York, 324 U.S. 401,417 (1945).

56. Harris v. United States, 331 U.S. 145, 160 (1947) (dissenting).

57. "Eighteen big states have seen fit to exert their power over a small number of little children ('and forbid them not')." Minersville School Dist. v. Gobitis, 108 F.2d 683 (C.C.A. 3d 1939). 
that of legislators and administrators, ${ }^{35}$ one would think that he would attempt to soften archaic specific restrictions in the Bill of Rights which "grew out of transient experience or formulated remedies which time might well improve" ${ }^{59}$ by reliance on the consensus of society's opinion of fundamental justice.

Which of the two reasons is Mr. Justice Frankfurter's is none too clear. On one occasion he said that his "power does not vary according to the particular provision of the Bill of Rights which is invoked. . . . In no instance is this Court the primary protector of the particular liberty invoked." " 0 This seems to mean that so far as the Federal Government is concerned the Bill of Rights hits equally hard in all respects regardless of society's opinion of fundamental justice. Yet when dissenting from a decision not applying the Fourth Amendment's unreasonable searches and seizures prohibition, he said, after conceding the importance of "stern enforcement of the criminal lav": "But in our democracy such enforcement presupposes a moral atmosphere and a reliance upon intelligence whereby the effective administration of justice can be achieved with due regard for those civilized standards in the use of the criminal law which are formulated in our Bill of Rights." 61 Are "civilized standards" the same in the Bill of Rights as they are in the Fourteenth Amendment? If they are not, then it is clear why Mr. Justice Frankfurter does not indicate from what society he obtains a consensus of opinion: he does not because there is no one society. If the "civilized standards" are the same, then his language is defective and the end of the sentence should read "those civilized standards in the use of the criminal law which are formulated in our Bill of Rights along with some archaic junk that is not necessary but must be enforced because it is included." "02

If all of his distinctions between the Bill of Rights as it applies to the Federal Government and as it applies through the Fourteenth Amendment are put together they can be reconciled. But not by reference to any consensus of society's opinion of fundamental justice. The reconciling factor is states' rights. A man who strongly believes in leaving the citizens of individual states free to work out their own problems and to preserve their own liberties would defer to state judges but not to lower federal judges, would enforce the Federal Bill of Rights strictly but would not carry it into the Fourteenth Amendment in toto. And

58. West Virginia Bd. of Educ. v. Barnette, 319 U.S. 624, 665 (1943).

59. Louisiana ex rel. Francis v. Resweber, 329 U.S. 459, 468 (1947).

60. West Virginia Bd. of Educ. v. Barnette, 319 U.S. 624, 648 (1943).

61. Davis v. United States, 328 U.S. 582, 615 (1946).

62. There is also the "alert deference" he accords to the state court below, but does not accord to lower federal courts. Or at least $I$ have not found any such "deference." 
Mr. Justice Frankfurter has indicated independently of this type of case his belief in the importance of states' rights. ${ }^{63}$

The trouble with this states' rights factor is that it plays havoc with his objective standard for determination of constitutionality of governmental activity. It is difficult to believe that society has evolved so intricate a theory as to hold that the "concept of ordered liberty" is influenced by the existence of a federal system. And it is even more difficult to postulate a consensus of society's opinion that matches Mr. Justice Frankfurter's combination of states' rights and protection of civil liberties. He will allow states freedom to experiment with administration of criminal justice, but not with freedom of speech; ${ }^{\text {c4 }}$ to experiment with flag-saluting, but not with free bus service for parochial schools. ${ }^{65}$ Conceivably, society might have such a consensus in the abstract; it seems inconceivable that society would get there by the use of a concept of states' rights.

Aside from all these theoretical difficulties with Mr. Justice Frankfurter's objective standard, there is the practical problem of applying it to concrete cases. That he is aware of this is clear from his acknowledgement that "judges among themselves may differ," and his belief that "alert deference to the judgment of the State court uncler review" will keep the differences under control. ${ }^{66} \mathrm{He}$ has said this cannot be "blind acceptance." $67 \mathrm{He}$ must, therefore, be saying that even though judges can agree on what is society's opinion, he reserves the privilege of applying it his way. But he cannot do that except by his own view of how best to enforce the objective rules he finds. By "the gradual process of judicial inclusion and exclusion," 68 he will clothe society's abstraction with reality. The reality is his, not society's.

It seems fair to conclude that Mr. Justice Frankfurter has postulated an objective standard of constitutionality that breaks down upon dissection. What, then, has Mr. Justice Frankfurter propounded? This is no simple matter, for it requires assertions as to what he really thinks as opposed to what he says. But tentatively, it can be argued that his objective standard is a way of expressing two things: his own set of

63. See, e.g., his dissents in Rice v. Santa Fe Elevator Corp., 331 U.S. 218, 238 (1947), Bethlehem Steel Co. v. New York SLRB, 330 U.S. 767, 777 (1947), First Iowa Hydro-Elec. Coop. v. FPC, 328 U.S. 152, 183 (1946), and Pacific Coast Dairy, Inc. v. Dept. of Agriculture of Calif., 318 U.S. 285, 296 (1943). And see Kirschbaum Co. v. Walling, 316 U.S. 517, 521-3 (1942), and FTC v. Bunte Bros., 312 U.S. 349, 351, 355 (1941), 50 YALE L.J. 1294 (1941).

64. Compare discussion pp. 585-6 supra, with discussion p. 582 supra.

65. Compare Minersville School Dist. v. Gobitis, 310 U.S. 586 (1940) with Everson v. Board of Education, 330 U.S. 1 (1947) (dissenting).

66. See text quotation accompanying note 51 supra.

67. See text quotation accompanying note 55 silpra.

68. Davidson v. New Orleans, 96 U.S. 97, 104 (1877), quoted by Justice Frankfurter in Louisiana ex rel. Francis v. Resweber, 329 U.S. 459, 471 (1947). 
values for his society and his own conception of the safe limits of his function. Some things he believes in strongly enough to use his power to protect them..$^{69}$ Others he may believe in but not strongly enough to risk the charge of abuse of office. These are not all the factors to be taken into account. Justices are not such uncomplicated mechanisms. ${ }^{70}$ But these are certainly two key factors which are more significant than his own words about the "impersonal standards of society which alone judges, as the organs of Law, are empowered to enforce." it

Mr. Justice Black also searches for an "impersonal standard" by which he can decide issues of constitutional limitations on government. But his method is the antithesis of MIr. Justice Frankfurter's. In Adamson v. California ${ }^{72}$ they both staged a full-dress review of their theories. Mr. Justice Black rejects the "consensus of society's opinion" theory, which he calls a "natural law" theory, ${ }^{73}$ for two reasons. First, he believes in the Bill of Rights and feels that "to hold that this Court can determine what, if any, provisions of the Bill of Rights will be enforced [under the Fourteenth Amendment], and if so to what degree, is to frustrate the great design of a written Constitution." "i4 Second, he

69. "Without a free press there can be no free society." Pennelsamp v. Florida, 328 U.S. 331, 354 (1946) (concurring).

70. I suppose someone might argue, for example, that MIr. Justice Franlfiurter is overly influenced by the English. See Harris v. United States, 331 U.S. 145, 171 (1947), Pennekamp v. Florida, 32S U.S. 331, 359 (1946), MIalinski v. New York, 324 U.S. 401, 419 (1945), MicNabb v. United States, 318 U.S. 332, 345 (1943).

71. See text quotation accompanying note 48 supro. Of course, if Mrr. Justice Frankfurter postulates a monistic theory of the state, in the nature of the Oxford idealism of Bosanquet, then he presumably is striving to make his decisions accord with the "real will" of society. See Bosanguet, The Philosophical Tukory of tae State 138-43, 215-6 (3d ed. 1920). But there are difficulties with this. In the first place, the adoption of such a theory is in itself a choice of a philosophy. Decisions would then be according to his "subjective philosophy." In the second place, decisions based on such a philosophy imply either that he thinks his ideas better approach the "real will" than do his brethren's, in which case they remain his ideas; or that he adheres to the absolute idealistic notion wherein his ideas are a "reflection" of the "real will," in which case his brethren's ideas are also "reflections" of the same "real will." Finally, "if this means that social life is ultimately the product of a single and rational mind organizing its activities in terms of a logical process, it is contrary to every fact we encounter in daily experience." LAsss, A Gramajar of Polittcs 34 (1925). See also Laski, Tue State ni Treonx aiod PracTICE 36-46 (1935). Obviously, I do not maintain that Mrr. Justice Franlfurter subscribes to Oxford idealism. I mention the possibility only because it seems to me one philosophical basis for his decisions by "impersonal standards of society" which would produce a form of objectivity. If this is the form of his objectivity, I think it infirm for the reasons above. If he does not accept the "real will" theory, then I revert to the argument in the text.

72. 332 U.S. 46 (1947).

73. Id. at 69 . See also his objections to "natural law" in International Shoe Co. v. State of Washington, 326 U.S. 310, 324-6 (1945) (separate opinion).

74. Adamson v. California, 332 U.S. 46, 89 (1947). 
feels that "this formula also has been used in the past and can be used in the future, to license this Court, in considering regulatory legislation, to roam at large in the broad expanses of policy and morals and to trespass, all too freely, on the legislative domain of the states as well as the Federal Government." 75

Mr. Justice Black's thesis is that he enforces the Bill of Rights because that is what the Constitution specifically provides for. He further asserts that a study of the history of the Fourteenth Amendment convinces him that the Bill of Rights was carried into the Fourteenth Amendment. Thus, he asserts an objective standard of constitutionality covering both state and national government.

Many technical difficulties have to be surmounted by Mr. Justice Black before he can defend his thesis as an objective standard. Whether his history is accurate is a question of importance that need not be dealt with here. ${ }^{76}$ Even if he were wrong, he could still defend his theory by a logical imputation to the states of a national standard of prohibitions of which the Bill of Rights could be considered the best evidence. Nor need he be disturbed by the logical by-play that "due process" cannot mean one thing in the Fifth Amendment and another thing in the Fourteenth. ${ }^{77} \mathrm{He}$ can, and does, answer this with a similar bit of by-play to the effect that "the provisions of the [Fourteenth] Amendment's first section, separately, and as a whole," incorporate the Bill of Rights. ${ }^{78}$ Thus he does not rely on "privileges and immunities" or on "due process." He relies on the Fourteenth Amendment.

What apparently does cause him trouble is the argument that he could hardly want to be so literal as to insist on every prohibition in the Bill of Rights. The argument is put thus: "Even the boldest innovator would shrink from suggesting to more than half the States that they no longer initiate prosecutions without indictment by grand jury, or that thereafter all the States of the Union must furnish a jury of twelve for every case involving a claim above twenty dollars." io Mr. Justice Black appears to hedge against such a literal transference when he says, "Whether this Court ever will, or whether it now should, in the light of past decisions, give full effect to what the [Fourteenth] Amendment was intended to accomplish is not necessarily essential to a decision here." 80 To the extent that he means this hedge to be effec-

75. Id. at 90 .

76. My a priori guess is that a great deal of historical research will produce the same inconclusive story that has come out of the controversy over the conspiracy theory. See Graham, The "Conspiracy Theory" of the Fotrteenth Amendment, 47 YALE L.J. 371 (1938), 48 YALE L.J. 171 (1938).

77. See Mr. Justice Frankfurter's concurring opinion in Adamson v. California, 332 U.S. 46, 59 (1947), for the argument.

78. Id. at 71 .

79. Id. at 64-5. This is from Mr. Justice Frankfurter's concurring opinion.

80. Id. at 75 . 
tive, his thesis differs not one whit from MIr. Justice Frankfurter's. They both put into the Fourteenth Amendment what they want to.

Mr. Justice Black's thesis has still other loopholes. First, he may not find in the Bill of Rights "specific" protection for everything he may want to protect. For example, there is no equal protection clause in the Bill of Rights. Would he deny equal protection where national action was in question? Or would he read equal protection backwards from the Fourteenth into the Fifth? What "specific" provision other than equal protection could he find that would forbid racial discrimination? Second, he may have to twist "specific" provisions in order to get under them when reliance on "due process" would be simpler. For example, in Tot v. United States, "81 a Congressional statutory presumption was invalidated for lack of due process in that the presumed fact had no "reasonable relation to the circumstances of life as we know them." 82 Mr. Justice Black concurred but apparently relied on the Sixth Amendment, which requires a public trial, and confronting an accused with the witnesses against him. ${ }^{83} \mathrm{He}$ also implied that the Sixth Amendment requires "where guilt is in issue, . . . the introduction of some evidence which tends to prove the elements of the crime charged." 84 A "fair trial" under the Sixth Amendment presumably implies reasonable presumptions, but it seems a little unnecessary to build such a structure just to avoid the use of "due process" language.

In theory Mr. Justice Black's thesis is objective in that he cannot go outside the "specific" prohibitions of the Bill of Rights and herein it differs from Mr. Justice Frankfurter's thesis inasmuch as the "consensus of society's opinion" is not a definite and unchanging catalog which can be observed by a third person. As a practical matter the two can arrive at the same result. For example, Millie Francis was not protected from electrocution after an initial failure. ${ }^{85} \mathrm{Mr}$. Justice Frankfurter said this was because the "consensus of society's opinion" would not protect Willie. ${ }^{86} \mathrm{Mr}$. Justice Black presumably thought Willie was not twice put in jeopardy or subjected to cruel and unusual punishment. ${ }^{87}$ Whether the Bill of Rights was in or out of the Fourteenth

81. 319 U.S. 463 (1943).

82. Id. at 468 .

83. U.S. Const. Aarend. VI.

84. Tot v. United States, 319 U.S. 463, 473 (1943). Mfr. Justice Douglas concurred with Mr. Justice Black.

85. Iouisiana ex rel. Francis v. Resweber, 329 U.S. 459 (1947).

86. Id. at 471 .

87. I say "presumably" because Mr. Justice Black silently concurred in Mir. Justice Reed's somewhat murky opinion. Mrr. Justice Reed said that he would assume that prohibitions against double jeopardy and cruel punishment were forbidden by the Fourtenth Amendment. But his demonstration sounds more like a simple conclusion that Willie was not denied "due process." It may be that I am reading by hindsight beesuse in Adamson v. California, 332 U.S. 46 (1947), Mr. Justice Reed spoke for the Court and 
Amendment was of no significance in deciding Willie's fate. Both agreed in Malinski v. New York ${ }^{8}$ on the need for a new trial, one because the Bill of Rights "commanded" it, the other because society "commanded" it. Furthermore, as a practical matter, society can "command" invalidation of state action when the Bill of Rights does not, ${ }^{89}$ or society can protect state action when the Bill of Rights "commands" invalidation. ${ }^{90}$

These two "objective" approaches both appear, therefore, to be sufficiently subjective that there is little value in choosing between them. Yet there is something to be said for preferring Mr. Justice Black's approach. In the first place, he has, somewhat like Chief Justice Stone, set forth his personal philosophy of absolute limitations on government as such even though he tries to put it in a framework of objectivity. "In my judgment," he says, "the people of no nation can lose their liberty so long as a Bill of Rights like ours survives and its basic purposes are conscientiously interpreted, enforced and respected so as to afford continuous protection against old, as well as new, devices and practices which might thwart those purposes." ${ }^{91} \mathrm{He}$ further concedes that since he interprets the Bill of Rights ". . . and since words can have many meanings, interpretation obviously may result in contraction or extension of the original purpose of a constitutional provision thereby affecting policy." ${ }_{92}$ The fair inference is that he will seek to further this philosophy of his which he has set forth. The "natural law" approach, on the other hand, gives no advance notice of what fundamental philosophy is at work.

In the second place, Mr. Justice Black's approach is more conducive to "judicial self-restraint" than is Mr. Justice Frankfurter's. As noted earlier, "self-restraint" is easily turned on or off. ${ }^{93}$ Nevertheless, by attempting to confine himself within "specific" words, Mr. Justice Black makes his task harder, which tends to curtail judicial free-wheeling. By contrast, there is no brake on spinning out a demonstration of the "consensus of society's opinion". This is not to imply that Mr. Justice Frankfurter exercises less self-restraint than Mr. Justice Black. In the realm of civil liberties, Mr. Justice Frankfurter is the more restrained in upsetting governmental action..$^{94}$ But as pointed out above,

rejected the theory of incorporation of the Bill of Rights into the Fourteenth Amendment. See p. 593 infra. Therefore, I suspect his heart was not in it when he assumed the theory in Willie's case. See note 98 infra.

88. 324 U.S. 401 (1945).

89. E.g., Everson v. Board of Education, 330 U.S. 1 (1947).

90. E.g., Adamson v. California, 332 U.S. 46 (1947).

91. Id. at 89.

92. Id. at $90-1$.

93. See p. $\mathbf{5 7 7}$ supra.

94. See Curtis, Lions Under the Throne, c. 16 (1947); Frank, The Unitcd States Supreme Court: 1946-47, 15 U. of CHI. L. REv. 1, 21 (1947). 
it is the extraneous factor of a belief in states' rights that causes Mr. Justice Frankfurter to be more self-restrained. ${ }^{95}$ The significant point is that as between the two theories as stated by the justices, the "specific" words approach is more difficult to manipulate verbally.

It is ironical, however, to compare the two approaches as if they were definitive. Of the other seven present members of the Court, only Mr. Justice Douglas appears wholeheartedly to accept either view. He concurs in Mr. Justice Black's dissent in the Adannson case. Mrr. Justice Murphy and Mr. Justice Rutledge somewhat ambiguously appear in the same case to accept both approaches. They agree that the Bill of Rights is included in the Fourteenth Amendment, but they do not stop there. "Occasions may arise," they say, "where a proceeding falls so far short of conforming to fundamental standards of procedure as to warrant constitutional condemnation in terms of a lack of due process despite the absence of a specific provision in the Bill of Rights." so In the Adamson case, the rest of the Court, after noting that the Fourteenth Amendment does not incorporate the Bill of Rights in toto, says that the issue is "whether the comment on failure to testify violates the protection against state action that the due process clause does grant to an accused." 97 There follows a long discussion citing Supreme Court cases, state cases, treatises, and law review articles. The conclusion is that the Due Process Clause was not violated. Why that conclusion is drawn is not clear. ${ }^{99}$

\section{Conclusion}

Here is a great quantity of sound and fury signifying what? Two present members of the Court produce theories of constitutional interpretation of governmental limitations designed to control themselves and their brethren. ${ }^{99}$ Each theory collapses, on analysis, into little

95. See pp. 587-\$ supra.

96. 332 U.S. 46,124 (1947).

97. Id. at 54 .

98. There is irony in the unsettled state of things. The present line-up is: Bill of Rights not in-Vinson, C.J., Reed, Frankfurter, Jackson, and Burton, JJ.; Bill of Rights in-Black, Douglas, Murphy, and Rutledge, JJ. If four of the former require one of the latter to constitute a majority, he can force his theory to be assumed, as in the Willic Francis case, see note 87 supra, or he can concur in the result and prevent a majority opinion. Cf. Gayes v. New York, 332 U.S. 145 (1947). The converse is partly true in that if one of the majority joins the four dissenters the latter must either tall: "due process" or allow a separate concurrence preventing a majority opinion. Sce Malinslia v. New York, 324 U.S. 401 (1945). Thus, the controversy can be kept alive for some time.

99. I have discussed this problem of objectivity almost solely in terms of the constitutional issues of limitations on government. Although the problem stands out more sharply here than in cases of distribution of power, either between state and nation or within the Federal Government, the problem is not different in lind. Sce, for example, Braden, Umpire to the Federal System, 10 U. OF CHI. L. Rev. 27, esp. pp. 23-31, 47-S (1942). 
more than a front for policy-making. No justice can be controlled except by those limitations, absolute, physical, and self-imposed, discussed earlier. Perhaps Mr. Justice Frankfurter measures his power, finds it precarious, and retreats. If so, that is the cause of the retreat, not "society's opinion." Perhaps Mr. Justice Black is stymied by an inability to maneuver around "specific" words. If so, it is a lack of ingenuity, a fear of criticism, or a judgment of the reaction to the transparency of his maneuver which stops him, not the "specific" words.

There is no objectivity in constitutional law because there are no absolutes. Every constitutional question involves a weighing of competing values. Some of these values are held by virtually everyone, others by fewer people. Supreme Court justices likewise hold values. The more widely held are the values in society, the more likely the Supreme Court will hold them; the more controversial the values, the more likely the Supreme Court is to divide over them. ${ }^{100}$ It is also true, as Mr. Justice Frankfurter says, that Supreme Court justices are "freed from the influences of immediacy and from the deflections of worldly ambition." 101 This enables them to hold to their values more consistenly than lesser people more precariously situated. But in any event it is their values which they seek to make effective. They may fail because their power is limited and to that extent they may have to follow a course more in line with the values held by others; but they will do so only because their power is limited, not because they accept other values.

Hence the justice who wants to tell the world how he decides cases must do what Chief Justice Stone did in a limited way and what Mr. Justice Black almost by accident did in a less limited way. He must say: "This is what I believe is important in our civilization and I shall do all I can to preserve it." And forthwith set forth his creed. ${ }^{102}$ If this is too shocking to society or if the many limitations on the Court's power are not in themselves believed to be sufficient to restrain the imposition of "idiosyncratic" values, then society must take away the Court's power. There is no middle ground.

100. "The division of opinion among the judges of the Supreme Court finds its counterpart in the differences among those who debate in other forums. . . Take a sampling from the men you talk with at the club and in the Pullman and you will find that their untrained common sense leads them to the same diverse conclusions to which the more highly developed instrument leads the judges." Powell, The Logic and Rhatoric of Constitutional Laze, 15 Journal of Peil., Psych. ANd Scientific Metrod 645, 647 (1918) reprinted in 1 Selected Essays on Constitutional Law 474, 476-7 (1938).

101. West Virginia Bd. of Educ. v. Barnette, 319 U.S. 624, 665 (1943).

102. See RutLedge, A Declaration of Legal Faith (1947). 